\title{
HOME VISIT OLEH GURU ATAU WALI KELAS DAN MOTIVASI BELAJAR SISWA
}

\author{
Eddy Abdullah \\ Sekolah Menengah Pertama Negeri 3 Matan Hilir Selatan \\ Email: eddyabdullahsmpn3sph@gmail.com
}

\begin{abstract}
Abstrak
Semakin hari kesadaran siswa terhadap tata tertib sekolah semakin berkurang. Selain dari kurang sadarnya siswa terhadap tata tertib, mulai tumbuh juga perilaku kenakalan remaja di kalangan siswa SMP Negeri 3 Matan Hilir Selatan. Permasalahan kenakalan remaja dan kesadaran siswa terhadap tata tertib sekolah akan sulit di atasi jika tidak ada kerjasama yang baik antara pihak sekolah dan orang tua. Terkadang pihak orang tua tidak menyadari bahwa kenakalan siswa juga dipengaruhi oleh pergaulan di luar lingkungan sekolah. Wali siswa hanya menuntut anaknya menjadi pandai di sekolah tanpa memperhatikan pergaulan anaknya di luar sekolah dan tidak pernah juga memotivasi anaknya untuk rajin belajar. Selain itu, pihak sekolah yang dalam hal ini diwakili oleh wali kelas jarang atau bahkan tidak pernah membicarakan perihal kenakalan siswa dengan wali siswa, sehingga masalah kenakalan siswa dan kurangnya motivasi belajar siswa di sekolah sulit untuk dicari jalan keluarnya. Sehingga peneliti tertarik melakukan home visit. Dari hasil penelitian didaptkan bahwa masih banyak pelanggaran-pelanggaran tata tertib yang dilakukan oleh siswa, baik siswa lakukan di dalam kelas saat belajar atau saat di luar kelas. Sedangkan motivasi belajar yang dimiliki siswa d SMP Negeri 3 Matan Hilir Selatan sangat beragam, ada yang motivasi belajarnya tinggi, sedang, kurang, dan ada juga beberapa yang mulai kehilangan motivasi belajar
\end{abstract}

\section{Kata Kunci : Home Visit, Wali Kelas, Motivasi Belajar}

\section{PENDAHULUAN}

Motivasi belajar siswa merupakan salah satu unsur penting dalam meraih keberhasilan siswa dalam menempuh pendidikan. Motivasi belajar siswa bisa di tumbuhkan melalui peran serta sekolah dan orang tua yang saling berkesinambungan. Selain itu, faktor lingkungan sekitar juga sangat mempengaruhi motivasi belajar siswa. Faktor lingkungan pergaulan siswa memunculkan perilaku yang mempengaruhi motivasi belajar siswa, seperti sikap siswa terhadap tata tertib sekolah dan perilaku yang condong kearah kenakalan remaja. Semakin hari kesadaran siswa terhadap tata tertib sekolah semakin berkurang.

Kurang sadarnya siswa terhadap tata tertib dipengaruhi oleh beberapa faktor seperti kurangnya perhatian orang tua terhadap perilaku siswa yang berkaitan dengan sekolah, pengaruh tontonan siswa terhadap tayangan televisi yang kurang mendidik,dan pergaulan siswa di sekolah yang kurang mendapatkan pantaun dari guru. Selain dari kurang sadarnya siswa terhadap tata tertib, mulai tumbuh juga perilaku kenakalan remaja di kalangan siswa SMP Negeri 3 Matan Hilir Selatan. Tumbuhnya kenakalan remaja di kalangan siswa banyak dipengaruhi oleh pergaulan yang tidak terkontrol, pergaulan dengan sesama remaja bahkan orang dewasa di lingkungan tempat tinggalnya. Beberapa contoh kenakalan remaja yang mulai menjangkit siswa siswi SMP Negeri 3 Matan Hilir Selatan seperti mulai mencoba merokok, mabuk lem, kecanduan game online hingga larut malam, dan mencoret-coret tubuh mereka seolah-olah bertato. 
Banyak akibat yang ditimbulkan dari perilaku siswa yang tidak taat terhadap tata tertib dan mulai terjangkit perilaku kenakalan remaja. Salah satu akibatnya adalah timbulnya rasa malas untuk bersekolah, hal tersebut dikarenakan oleh terlalu seringnya siswa berurusan dengan guru berkaitan dengan pelanggaran tata tertib sekolah. Siswa yang bermasalah sudah pasti sering mendapatkan teguran dan hukuman dari guru, sehingga siswa tersebut timbul rasa malas bersekolah dan belajar. Setelah siswa malas belajar pada akhirnya nilai-nilai akademis siswa akan merosot.

Permasalahan kenakalan remaja dan kesadaran siswa terhadap tata tertib sekolah akan sulit di atasi jika tidak ada kerjasama yang baik antara pihak sekolah dan orang tua. Terkadang pihak orang tua tidak menyadari bahwa kenakalan siswa juga dipengaruhi oleh pergaulan di luar lingkungan sekolah. Wali siswa hanya menuntut anaknya menjadi pandai di sekolah tanpa memperhatikan pergaulan anaknya di luar sekolah dan tidak pernah juga memotivasi anaknya untuk rajin belajar. Selain itu, pihak sekolah yang dalam hal ini diwakili oleh wali kelas jarang atau bahkan tidak pernah membicarakan perihal kenakalan siswa dengan wali siswa, sehingga masalah kenakalan siswa dan kurangnya motivasi belajar siswa di sekolah sulit untuk dicari jalan keluarnya.

Sesuai dengan permasalahan di atas, penelitian ini bertujuan untuk (1) mendeskripsikan kondisi kedisiplinan dan motivasi belajar siswa di SMP Negeri 3 Matan Hilir Selatan, (2) Untuk mendeskripsikan interaksi antara wali kelas dan wali murid di SMP Negeri 3 Matan Hilir Selatan, (3) Untuk mendeskripsikan skenario Home Visit untuk meningkatkan kedisiplinan siswa, motivasi belajar siswa, dan interaksi yang baik antara wali kelas dan wali murid. Menurut Sheafor dan Horejsi dalam Pujileksono (2018:19), kunjungan rumah (home visit) adalah komponen penting dari semua layanan penjangkauan dan sangat penting untuk klien yang sulit dijangkau. Ada banyak tujuan kunjungan rumah yang dapat dirumuskan, sesuai dengan permasalahan dan kondisi keluarga.

Menurut Pujileksono (2018:25) adapun tujuan kunjungan rumah pada latar sosial anak dan keluarga diantaranya: (1) Mempromosikan hubungan orang tua dan anak yang positif. (2) Meningkatkan pen-getahuan dan ketrampilan mengasuh anak, (3) Membantu perkembangan anak secara sehat.Membantu keluarga mengakses jaringan layanan formal dan informal dan mendukung tersedia layanan di komunitas mereka sendiri, (4) Mempromosikan kesehatan keluarga (5) Membantu membangun komunitas yang kuat. Dengan demikian secara tidak langsung home visit dapat meningkatkan motivasi belajar siswa.

Motivasi adalah usaha yang didasari untuk mengerahkan dan menjaga tingkah seseorang agar ia terdorong untuk bertindak melakukan sesuatu sehingga mencapai hasil atau tujuan tertentu. Motivasi belajar adalah suatu perubahan tenaga di dalam diri seseorang (pribadi) yang ditandai dengan timbulnya perasaan dan reaksi untuk mencapai tujuan (Frederick J.Mc.Donald dalam H Nashar, 2004:39). Tetapi menurut Clayton Aldelfer dalam H.Nashar (20004:42) motivasi belajar adalah kecenderungan siswa dalam melakuka kegiatan belajar yang didorong oleh hasrat untuk mencapai prestasi hasil belajar sebaik mungkin. Jadi motivasi belajar adalah kondisi psikologis yang mendorong siswa untuk belajar secara sungguh-sungguh, yang pada gilirannya akan terbentuk cara belajar siswa yang sistematis, penuh konsentrasi dan dapat menyeleksi kegiatan-kegiatannya. Motivasi muncul dari berbagai pihak, satu diantarnya adalah wali kelas.

Wali kelas adalah guru yang diberi wewenang oleh kepala sekolah untuk membimbing siswa dalam satu kelas. Wali kelas juga berperan dalam program bimbingan dan konseling di sekolah terutama dalam membantu siswa dalam menghadapi masalah. Berikut beberapa peran wali kelas dalam bimbingan dan konseling diantaranya: (1) Peran wali kelas sebagai mitra konselor, (2) Peran wali kelas sebagai pengelola kelas tertentu dalam bimbingan dan konseling, (3) 
Peran wali kelas sebagai konselor dalam bimbingan konseling. Sebagai-mana kita ketahui wali kelas juga mempunyai tanggung jawab dalam melaksanakan perannya sebagai konselor, wali kelas harus dapat membantu para siswa keluar dari masalah yang dapat mengganggu konsentrasi belajarnya. Apabila wali kelas tidak dapat membantu siswa keluar dari permasalahan yang dihadapi, maka wali kelas harus bekerja sama dengan staf sekolah yang lain.

\section{METODE PENELITIAN}

Penelitian ini dirancang untuk dilakukan dalam tiga siklus. Menurut pengertiannya penelitian tindakan adalah penelitian tentang hal-hal yang terjadi dimasyarakat atau sekolompok sasaran, dan hasilnya langsung dapat dikenakan pada masyarakat yang bersangkutan (Arikunto, 2002:82).

Ciri atau karakteristik utama dalam penelitian tindakan adalah adanya partisipasi dan kolaborasi antara peneliti dengan anggota kelompok sasaran. Penelitian tidakan adalah satu strategi pemecahan masalah yang memanfaatkan tindakan nyata dalam bentuk proses pengembangan invovatif yang dicoba sambil jalan dalam mendeteksi dan memecahkan masalah. Dalam prosesnya pihak-pihak yang terlibat dalam kegiatan tersebut dapat saling mendukung satu sama lain. Sedangkan tujuan penelitian tindakan harus memenuhi beberapa prinsip sebagai berikut: (1) Permasalahan atau topik yang dipilih harus memenuhi kriteria, yaitu benar-benar nyata dan penting, menarik perhatian dan mampu ditangani serta dalam jangkauan kewenangan peneliti untuk melakukan perubahan. (2) Kegiatan penelitian, baik intervensi maupun pengamatan yang dilakukan tidak boleh sampai mengganggu atau menghambat kegiatan utama. (3) Jenis intervensi yang dicobakan harus efektif dan efisien, artinya terpilih dengan tepat sasaran dan tidak memboroskan waktu, dana dan tenaga. (4) Metodologi yang digunakan harus jelas, rinci, dan terbuka, setiap langkah dari tindakan dirumuskan dengan tegas sehingga orang yang berminat terhadap penelitian tersebut dapat mengecek setiap hipotesis dan pembuktiannya. (5) Kegiatan penelitian diharapkan dapat merupakan proses kegiatan yang berkelanjutan (on-going), mengingat bahwa pengembangan dan perbaikan terhadap kualitas tindakan memang tidak dapat berhenti tetapi menjadi tantangan sepanjang waktu. (Arinkunto, 2002:82-83).

Tempat penelitian adalah tempat yang digunakan dalam melakukan penelitian untuk memperoleh data yang diinginkan. Penelitian ini bertempat di SMPN 3 Matan Hilir Selatan.

Waktu penelitian adalah waktu berlangsungnya penelitian atau saat penelitian ini dilangsungkan. Penelitian ini dilaksanakan pada bulan Agustus sampai dengan November semester ganjil tahun pelajaran 2018/2019. Subyek penelitian adalah siswa-siswi SMPN 3 Matan hilir Selatan Tahun Pelajaran 2018/2019 Penelitian ini dilaksanakan melalui 5 tahap, yaitu, (1) tahap perencanaan, (2) tahap persiapan, dan (3) tahap pelaksanaan, (4) tahap pengolahan data, dan (5) penyusunan Laporan. Tahap-tahap tersebut dapat dirinci seperti sebagai berikut. Pada tahap perencanaan ini kegiatan yang dilakukan meliputi, (1) observasi di sekolah, (2) penyusunan proposal penelitian. Pada tahap persiapan ini meliputi, (1) pembuatan RP (rencana pembelajaran), (2) pembuatan LO (lembar observsi) minat perhatian dan partisipasi siswa, (3) pembuatan soal tes formatif, (4) pembuatan rambu-rambu penilaian, (5) uji coba instrumen, dan (6) seleksi dan revisi instrumen. Tahap pelaksanaan merupakan kegiatan yang banyak berhubungan dengan lapangan dan pengolahan hasil penelitian. Tahap pelaksanaan meliputi, (1) tahap pengumpulan data dan (2) tahap pengolahan data. Pada tahap ini meliputi, (1) penyusunan laporan penelitian dan (2) penggandaan laporan. Pada penelitian ini menggunakan teknik analisis deskriptif kualitatif, yaitu suatu metode penelitian yang bersifat menggambarkan kenyataan atau fakta sesuai dengan data yang diperoleh dengan tujuan untuk mengetahui prestasi belajar yang 
dicapai siswa juga untuk memperoleh respon siswa terhadap kegiatan pembelajaran serta aktivitas siswa selama proses pembelajaran. dilakukan dengan cara memberikan evaluasi berupa soal tes tertulis pada setiap akhir putaran

\section{HASIL DAN PEMBAHASAN}

Siswa SMP Negeri 3 Matan Hilir Selatan yang motivasinya sedang dan kurang didominasi oleh siswa yang nilainya paspasan hanya sekedar sedikit di atas KKM atau sesuai dengan KKM. Siswa yang termasuk dalam kategori ini jumlahnya paling banyak. Siswa dalam kategori ini memandang sekolah hanya sekedar untuk naik kelas dan hadir setiap hari, mereka tidak peduli pada prestasi bahkan nilai akademis mata pelajaran. Siswa SMPN 3 Matan Hilir Selatan yang sudah mulai kehilangan motivasi terlihat dari kesehariannya disekolah yang sering berurusan dengan bagian kesiswaan atau guru BK karena berbagai macam jenis pelanggaran. Ada bermacam-macam tartib yang dilangar oleh siswa dalam kategori ini, seperti tindakan yang kurang sopan terhadap guru, pulang sekolah lebih awal, memprovokasi siswa lain melanggar tata tertib, berkelahi, dan merusak fasilitas sekolah.

Hasil penelitian lain yang diperoleh adalah masih banyak pelanggaranpelanggaran tata tertib yang dilakukan oleh siswa, baik siswa lakukan di dalam kelas saat belajar atau saat di luar kelas. Beberapa contoh pelanggaran tata tertib di dalam kelas seperti, buku pelajaran tertinggal, tidak mengerjakan PR, tidak memasukkan baju saat pelajaran, makan di kelas saat tidak ada guru, dan tidak melaksanakan tugas piket membersihkan kelas. Pelanggaran tata tertib di luar kelas pun kerap dilakukan oleh siswa. Hal tersebut dilakukan siswa karena mereka merasa tidak diawasi oleh guru. Peneliti kerap memperhatikan siswa melanggar tata tertib saat diluar kelas, seperti membuang sampah sembarangan, baju tidak dimasukkan, berkata-kata kotor untuk mengolok-olok kawan, baju seragam tidak rapi dan kadang- kadang sampai ada yang
Untuk mengalinasis tingkat keberhasilan atau persentase keberhasilan siswa setelah proses belajar mengajar setiap putarannya berkelahi karena kesalahpahaman. Pelanggaran tata tertib yang dilakukan oleh siswa rata-rata masih dalam batas normal atau biasa, tetapi sesekali peneliti menemui pelanggaran yang dilakukan siswa cenderung mengarah ke perilaku kenakalan remaja, seperti membantah atau melawan nasihat guru, merokok di lingkungan sekolah dan berkelahi. Namun pelanggaran tersebut hanya dilakukan oleh beberapa siswa saja yang memang membutuhkan perhatian khusus dari wali kelas dan wali murid. Sedangkan motivasi belajar yang dimiliki siswa d SMP Negeri 3 Matan Hilir Selatan sangat beragam, ada yang motivasi belajarnya tinggi, sedang, kurang, dan ada juga beberapa yang mulai kehilangan motivasi belajar. Motivasi belajar merupakan dorongan siswa untuk belajar sebaik mungkin untuk menggapai cita-cita. Motivasi tersebut muncul dari kesadaran diri sendiri dan pengaruh lingkungan.

Motivasi belajar yang tinggi biasanya dimiliki oleh siswa-siswa yang berprestasi. Motivasi tinggi tersebut disebabkan oleh dorongan orang tua yang tinggi karena orang tua ingin anaknya berhasil dalam jenjang pendidikan SMP. Selain itu, siswa yang motivasi belajarnya tinggi terlihat dari aktivitasnya di sekolah, mereka lebih aktif dalam berbagai kegiatan sekolah dan mempunyai rasa ingin tau yang tinggi.Siswa yang motivasinya sedang dan kurang didominasi oleh siswa yang nilainya paspasan hanya sekedar sedikit di atas KKM atau sesuai dengan KKM. Siswa yang termasuk dalam kategori ini jumlahnya paling banyak. Siswa dalam kategori ini memandang sekolah hanya sekedar untuk naik kelas dan hadir setiap hari, mereka tidak peduli pada prestasi bahkan nilai akademis mata pelajaran. Siswa SMP Negeri 3 Matan Hilir Selatan yang sudah mulai kehilangan motivasi terlihat dari kesehariannya di sekolah yang sering berurusan dengan bagian kesiswaan atau guru BK karena berbagai macam jenis pelanggaran. Ada 
bermacam-macam tata tertib yang di langgar oleh siswa dalam kategori ini,seperti tindakan yang kurang sopan terhadap guru, pulang sekolah lebih awal, memprovokasi siswa lain untuk melanggar tata tertib, berkelahi dan merusak fasilitas sekolah.

Pelanggaran tersebut berdasarkan pengamatan peneliti disebabkan oleh kurangnya pengawasan guru saat siswa berada di luar kelas, siswa mencari perhatian guru karena di rumah tidak mendapat perhatian yang cukup dari orang tua, pengaruh kecanduan gadget/ handphone, dan pergaulan yang salah di luar sekolah.Interaksi antara wali kelas dan wali murid sangat berpengaruh terhadap motivasi belajar siswa, terutama siswa yang mulai kehilangan motivasi belajar. Interaksi yang dilakukan oleh wali kelas dan wali murid di SMP Negeri 3 Matan Hilir Selatan sampai saat ini hanya sebatas saat penerimaan siswa baru, pembagian hasil ulangan umum tiap semester, dan kadang wali murid datang ke sekolah saat mendengar anaknya diperlakukan kasar oleh guru. Seharusnya kedua pihak saling bekerja sama untuk mendidik siswa agar menjadi lebih baik.

Ada beberapa faktor yang telah peneliti amati dan tanyakan langsung kepada wali kelas perihal minimnya interaksi dengan wali murid. Pertama, belum terbiasanya wali murid datang ke sekolah menanyakan perihal tingkah laku anaknya di sekolah. Hal tersebut dikarenakan kebiasaan orang tua yang tidak mau tahu dengan kondisi anaknya disekolah, orang tua hanya menuntut anaknya pandai karena sudah di didik oleh guru. Kedua, belum terbiasanya wali kelas mendatangi rumah wali murid untuk melaporkan atau mencari penyelesain tentang masalah siswa yang terjadi di sekolah. Masalah dianggap selesai tanpa campur tangan wali murid padahal sebenarnya wali murid juga perlu tahu permasalahan yang dialami siswa disekolah.

Berdasarkan dua faktor minimnya interaksi antara wali kelas dan wali murid di atas, maka peneliti ingin menyampaikan sebuah gagasan tentang perlunya kunjungan rumah yang dilakukan oleh wali kelas kepada wali siswa atau biasa disebut dengan home visit. Hal tersebut bertujuan agar motivasi siswa dalam belajar bisa tumbuh dan semangat belajar siswa dapat meningkat.

Pelaksanaan home visit yang dilakukan oleh wali kelas perlu memperhatikan berbagai hal agar tidak terjadi kesalahpahaman antara pihak sekolah dan wali murid. Apabila sudah terjadi kesalahpahaman maka kegiatan home visit akan sia-sia dan memungkinkan munculnya masalah baru yang menyebabkan kurangnya kepercayaan wali murid kepada pihak sekolah. Skenario pelaksanaan home visit kepada wali murid ini diadopsi dari pelaksanaan home visit yang dilakukan oleh pekerja sosial terhadap klien. Berikut adalah skenario yang dilakukan wali kelas terhadap wali murid.

Pertama. Membangun hubungan yang baik sebelum memasuki rumah wali murid. Berikut hal yang perlu dilakukan oleh wali kelas saat pertama kali datang ke rumah wali murid (1) Mengetuk pintu rumah dan mengucapkan salam dengan sopan. Mengetuk pintu dengan cara yang sopan dan tidak terlalu keras yang disertai dengan salam. Diusahakan tidak mengintip melalui jendela apabila tidak ada jawaban atau respon, karena hal seperti itu merupakan adab bertamu. Apabila sampai tiga ketukan pintu tidak ada yang menyahut, maka wali kelas harus menanyakan kepada tetangga untuk mengetahui ada tidaknya penghuni rumah. (2) Memperkenalkan diri dengan menyebutkan nama. Wali kelas memperkenalkan diri secara lengkap kepada wali murid. Setelah itu menjelaskan maksud dan tujuan dari kedatangannya ke rumah wali murid. (3) Sebelum dipersilahkan masuk, wali kelas mohon izin untuk masuk ke dalam rumah. Hal ini perlu disampaikan karena dikhawatirkan akan mengganggu aktivitas wali murid, seperti saat wali murid sedang bersih-bersih rumah, atau sedang ada pekerjaan lain yang menjadikan isi rumah terlihat berantakan. Wali kelas harus bersabar jika wali murid tersebut meminta wali kelas untuk menunggu sebentar karena akan membereskan ruang tamu yang 
berantakan. (3) Setelah masuk ke dalam rumah ikuti arahan tuan rumah mengenai tempat duduk. Hal ini perlu di perhatikan wali murid karena berkaitan dengan sopan santun. Wali kelas harus mengikuti arahan dari wali murid terkait dengan tempat duduk. (4) Perhatikan aturan yang berlaku di rumah wali murid. Wali kelas harus cepat memahami aturan-aturan yang ada di rumah tersebut seperti melepas sandal atau sepatu saat masuk rumah, atau menghentikan percakapan saat terdengar kumandang adzan.

Kedua. Mengenali situasi dan kondisi fisik rumah. Wali kelas dalam kunjungannya perlu beradaptasi dengan cepat dalam mengenali situasi dan kondisi rumah maka kegiatan yang dilakukan akan. berjalan lancer dan hambatan akan segera teratasi. Beberapa hambatan yang mungkin di temui saat wawancara seperti tempat duduk yang kurang nyaman saat akan digunakan untuk menulis, suara bising yang berasal dari televisi atau radio, dan anak kecil yang ada dalam keluarga siswa. Oleh karena itu, perlu segera diantisipasi dengan cepat apabila hambatan-hambatan tersebut muncul agar pelaksanaan wawancara berjalan lancar.

Ketiga. Menjaga etika agar tetap professional. Wali kelas dalam kunjungannya harus tetap bersikap professional dan menjaga etika. Profesionalitas harus tetap dipegang teguh wali kelas, jangan sampai terpengaruh dengan kondisi yang memprihatinkan keluarga siswa saat sedang melakukan kunjungan. Bukan berarti menghilangkan rasa empati kita terhadap kondisi memprihatinkan keluarga siswa, tetapi wali kelas tetap berpegang teguh pada tujuan utama menyelesaikan masalah siswa bersama- sama dengan wali murid. Jangan sampai ketika melihat kondisi yang memprihatinkan merubah tujuan utama kunjungan wali kelas, dengan menganggap semua permasalahan selesai tanpa melakukan diskusi atau kesepakatan dengan wali murid.
Keempat. Memperhatikan ruang privat yang berkaitan dengan siswa. Wali kelas diharapkan dapat melihat ruang privat siswa, seperti kamar tidur dan tempat santai siswa. Hal ini bisa dilakukan apabila wali murid mengizinkan wali kelas melakukan observasi. Hal ini bertujuan untuk melihat kebiasaan siswa melalui kondisi tempat privat tersebut. Selain itu, untuk memastikan bahwa tempat privat tersebut aman dan mendukung siswa untuk kegiatan belajar di rumah.

Kelima. Memperhatikan masalah keamanan lingkungan sekitar rumah. Keamanan wali kelas yang melakukan home visit siswa perlu diperhatikan, khususnya siswa yang bermasalah dengan narkotika, pencurian dan tindak criminal lainnya. Atau saat wali kelas memasuki lingkungan siswa yang merupakan pemukiman yang tingkat kerawanan dan kejahatannya tinggi. Pastikan kepala sekolah dan rekan guru lain mengetahui secara jelas lokasi yang dikunjungi saat home visit siswa. Alat komunikasi (handphone) harus dalam posisi aktif saat melakukan home visit. Keamanan wali kelas saat melakukan home visit bisa saja terancam saat terjadi penolakan keluarga atau masyarakat pada wali kelas.

Keenam. Memperhatikan manajemen waktu saat kunjungan. ketujuh mengakhiri kunjungan. Ada beberapa hal yang disarankan saat melakukan home visit sebagai berikut, (1) Buatlah janji dengan wali murid atau keluarga wali murid bahwa wali kelas akan melakukan home visit. Hal itu bisa dilakukan melalui surat yang dititip kepada siswa yang bersangkutan atau siswa lain yang rumahnya berdekatan. (2) Pertimbangkan waktu saat wali murid berada di rumah, seperti jam setelah pulang kerja atau waktu hari libur apabila wali murid tidak keberatan. (3) Membawa berkas-berkas yang berkaitan dengan permasalahan yang dihadapi oleh siswa. Berkas tersebut bisa berupa, buku pelanggaran tata tertib, absensi, catatan guru mata pelajaran, daftar nilai mata pelajaran atau arsip surat panggilan yang tidak sampai ke wali murid. Berkas tersebut bertujuan sebagai bukti bahwa perilaku dan 
motivasi belajar anak di sekolah sedang mengalami masalah. (4) Bersama-sama dengan wali murid mencari solusi untuk memecahkan masalah yang dihadapi oleh siswa sehingga motivasi belajar siswa dapat meningkat dan terjadi perubahan perilaku ke arah yang lebih baik. (5) Membuat komitmen bersama yang bertujuan agar siswa benarbenar meningkatkan motivasi belajar dan merubah perilaku menjadi lebih baik. (6) Menyiapkan nomor kontak pribadi wali kelas atau nomor kontak sekolah, apabila wali murid membutuhkan bantuan berkaitan dengan permasalahan yang dihadapi oleh siswa.

Ketujuh. Mengakhiri kunjungan, sebelum mengakhiri home visit, wali kelas perlu melakukan hal berikut, (1) Memastikan tunjuan home visit telas tercapai sesuai rencana. (2) Pastikan merangkum informasi yang diperoleh dari siswa dan wali murid serta tetangga sekitar. (3) Berikan kesempatan kepada siswa dan wali murid untuk mendiskusikan perkembangan permasalahan yang diselesaikan selama home visit. (4) Bila memungkinkan, beritahu siswa beserta walinya tentang langkah atau rencana wali kelas selanjutnya. (5) Berikan nomor kontak pribadi wali kelas yang dapat dihubungi sewaktu- waktu, dan mintalah nomor pribadi siswa serta walinya. (6) Pastikan bahwa wali kelas bisa dihubungi sewaktu-waktu untuk menyelesaikan masalah yang dihadapi oleh siswa. (7) Apabila ada kunjungan lanjutan, maka sampaikan pada siswa dan walinya bahwa home visit berikutnya akan diberitahukan jadwalnya.

\section{SIMPULAN DAN SARAN Simpulan}

Berdasarkan paparan dari pembahasan dapat disimpulkan sebagai berikut, (1) Motivasi belajar siswa di SMP Negeri 3 Matan Hilir Selatan bervariatif, ada yang motivasi belajarnya tinggi, sedang, rendah, dan mulai kehilangan motivasi dalam belajar. Perlu mendapat perhatian khusus bagi siswa yang motivasinya rendah dan siswa yang kehilangan motivasi agar dapat tumbuh kembali motivasi belajarnya. Selain itu, masih banyak pelanggaran siswa terhadap tata tertib sekolah. Hal tersebut perlu mendapat perhatian khusus oleh wali kelas, karena pelanggaran yang dilakukan oleh siswa dapat mempengaruhi motivasi belajar siswa yang bersangkutan. (2) Interaksi yang dilakukan oleh wali kelas dan wali murid di SMP Negeri 3 Matan Hilir Selatan sampai saat ini masih sangat jarang dilakukan. Ada beberapa faktor yang telah peneliti amati dan tanyakan langsung kepada wali kelas perihal minimnya interaksi dengan wali murid. Pertama, belum terbiasanya wali murid datang ke sekolah menanyakan perihal tingkah laku anaknya di sekolah.. Kedua, belum terbiasanya wali kelas mendatangi rumah wali murid untuk melaporkan atau mencari penyelesain tentang masalah siswa yang terjadi di sekolah. Berdasarkan dua faktor minimnya interaksi antara wali kelas dan wali murid di atas, maka peneliti ingin menyampaikan sebuah gagasan tentang perlunya kunjungan rumah yang dilakukan oleh wali kelas kepada wali siswa atau biasa disebut dengan home visit. (3) Dalam scenario home visit, dimungkinkan dapat meningkatnya interaksi yang baik antara pihak sekolah yang diwakili oleh wali kelas dengan pihak siswa yang diwakili oleh wali murid, sehingga motivasi belajar siswa dapat meningkat. Selain itu, dimungkinkan berkurangnya tingkat pelanggaran tata tertib sekolah yang dilakukan oleh siswa sehingga tercipta lingkungan dan budaya sekolah yang disiplin.

\section{Saran}

Berdasarkan pembahasan dan kesimpulan di atas, dapat disarankan beberapa hal sebagai berikut, (1) Wali kelas selalu memantau perkembangan anak yang berkaitan dengan motivasi belajar dan tingkat kedisiplinan terhadap tata tertib, agar tidak terjadi penurunan pada kedua hal tersebut. (2) Wali murid harus selalu memantau perkembangan motivasi belajar, nilai akademis dan perilaku siswa baik di lingkungan sekolah atau di luar sekolah. Hal 
tersebut perlu dilakukan agar siswa terhindar dari perilaku kenakalan remaja yang dapat menghancurkan masa depan dan cita-cita siswa.

DAFTAR PUSTAKA

http://berkarya.um.ac.id/p=5504/ 2011/10/09 09.15

http://makalah.blogspot.com/2013/10/penge rtian-wali-kelas.html

Nashar, Drs.2004.Peranan Motivasi dan Kemampuan awal dalam kegiatan pembelajaran.Jakarta:Delia press.

Pujileksono, Sugeng. 2018. Home Visit
Pekerjaan Sosial. Malang: Intrans Publishing.

Sardiman, A.M.2000.Interaksi dan Motivasi Belajar Mengajar.Jakarta Grafindo Persada.

Sumarno, D. (1998). Pedoman Pelaksanaan Disiplin Nasional dan Tata Tertib Sekolah . Jakarta : C.V. Jaya Abadi.

W.J.S, Poerwodarminto. (1984). Kamus Besar Bahasa Indonesia. Jakarta : Balai Pustaka. 